are accumulated at this time, and normal cell proliferation and replacement takes place. When larvæ become infected at an earlier stage, death from the effect of the disease occurs before these abnormal proliferations progress very far. The infection process and abnormal cell proliferations continue in the eonymphal gut. The sizes of the tumours depend on the areas of cell infection. In the case of total infection there is a general swelling of the entire eonymphal gut. The centre of a growing tumour consists of an accumulation of dead cells. This is surrounded by greatly enlarged infected cells. The whole is surrounded by a mass of proliferating cells (Fig. 2).

The tumours rapidly mature during an early stage of pupation. Cell infection and abnormal cell proliferation cease at the time of the normal disintegration of the digestive cells of the eonymphal gut. General infection takes place after the adult gut is formed, but from the time of the breakdown of the eonymphal digestive epithelium until the adult gut is formed cell infection by the virus appears to be inhibited. If the infection process and tumour formation have not continued too far, a normal gut may be formed around the tumours and the insect survives. Many of the tumours remain within the gut during pupation. Because the mid-gut of the adult is much shorter than that of the eonymph, some of the tumours may be pushed out into the body cavity during pupation, where they remain as non-living, hard, dark-brown pellets throughout the life of the adult. Those which remain within the gut are subject to the action of digestive juices and may disappear. The mature tumour consists of a necrotic, pigmented mass of epithelial cells surrounded by thin tissue layers formed from the small proliferating cells (Fig. 3).

There is no evidence of infiltration of the tumour cells into any other organ in the spruce sawfly. All the evidence indicates that the tumours are nonmalignant.

${ }^{1}$ Paillot, A., Ann. des Epiphyties et Phytogenetique, 2, N.S., 341 (1936), 'Stark, M. B., J. Cancer Res., 3, 278 (1918).

s Stark, M. B., J. Exp. Zool., 27, 509 (1919).

- Stark, M. B., Amer. J. Cancer, 31, No. 2, 253 (1939).

'Russell, S. E., J. Exp. Zool., 84, 363 (1940).

- Federley, H., Hereditas, 22, 193 (1936).

7 Pflugfelder, O., Z. wiss. Zool., 151, 149 (1938).

${ }^{8}$ Scharrer, B., Proc. Soc. Exp. Biol. and Med., 60, 184 (1945).

- Balch, R. E., and Bird, F. T., Sei. Agric., 25, 2 (1944).

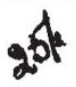

\section{SOUTH-EASTERN UNION OF SCIENTIFIC SOCIETIES}

$\mathrm{T}$ HE fifty-thrd annual congress of the SouthEastern 4 id Sof Scientific Societies was held at Canterbury D. Ang April 19-23, at the invitation of the May/r and dorporation, with the co-operation of the Dean laind Chapter.

In hits address the president, Mr. F. H. Edmunds, district geologist for south-east England in the Geological Survey, gave a broad picture of the evolution of State Geological Surveys in the various countries of the world. He indicated how their inception, in the first half of the nineteenth century, was intimately linked with the birth and growth of the science of geology, which itself is but some 150 years old. The basic principles of geological science were formulated largely as the result of the work of James Hutton in
Scotland and William Smith in England; Smith produced the first real geological map. Once these principles had been grasped, the economic importance of the geological map became immediately apparent to Governments everywhere. The Geological Survey of Great Britain was established in 1835, and it was almost immediately followed by those of Canada and India. To-day practically every civilized country in the world possesses its Geological Survey.

Mr. Edmunds said that geological research is the scientific study of the foundation of all our surround. ings, and its application touches us, either directly or indirectly, in our everyday life in many directions; one obvious way is in assisting in the discovery of economic minerals-coal, oil, minerals, etc.-and there are also numerous other less apparent ways. Geological maps of a country which give detailed accurate data of the surface layers of the land are particularly valuable in densely populated countries, in connexion with the many and widespread civil engineering works which are always in progress and which vary from foundation work for buildings to bridge-building, road-making and surface water storage, reservoir and dam.building, and from digging trenches for water, gas and sewage mains to sinking wells for water supply. Geological Surveys have also a cultural function, instanced by the identification by the Geological Survey of Great Britain of the types of rock and, in many cases, of their sources, which were used in making archæological objects, such as those revealed in bombed sites in Canterbury during the Second World War.

As social development proceeds towards planning and nationalization, as it is doing in Great Britain, the influence of the work of a Geological Survey on the implementation of policies becomes very great. Again quoting Great Britain, Mr. Edmunds said that not only was the Geological Survey the official adviser to the Coal Board, but its work also provides the basic data for decisions by central and local planning authorities relative to such matters as where and how sand, gravel, building stones, brick, cement, etc., should be quarried or manufactured ; indeed, no other basic criteria exist. The search for natural reserves of underground water has long been the function of the Geological Survey; without this previous work, regulation and conservation of underground water, now rendered necessary largely owing to great increases in daily consumption, would be impracticable.

An address on "Roman Canterbury" was delivered to the Archæological Section by its president, S. S. Frere, who also conducted a tour of the recent excavations in the City to illustrate points in his address. The keeper of manuscripts at the Cathedral Library, W. Urry, gave a paper on "The Street Plan of Mediæval Canterbury", and later demonstrated to the members on site. Excursions to Minster, Ebbs. fleet, Sandwich and Richborough were conducted by Dr. H. Raven. Dr. George Taylor became president of the Botanical Section, the subject of his address being "Remarks upon the Genus Potamogeton". Francis Rose gave a paper upon "Gaps in our Knowledge of the Flora of Kent", and conducted an excur. sion to Stodmarsh and Trenley Park Wood.

The president of the Geological Section, Arthur Wrigley, spoke on "The Thanet Sand", and conducted an excursion to Bishopstone Gap to examine the Lower Eocene rocks. A paper on "Notes on the Minerals of the Mesozoic and Later Strata of S.-E. England" was given by J. C. Taylor. A joint 
excarsion with the Botanical Section to demonstrate the agricultural soils of Kent was conducted by B. S. Furneaux.

The Zoological Section, under the presidency of Major Maxwell Knight, held a symposium on Nature study, with particular reference to the need for co-operation between the museum, laboratory and field-worker. The leaders on the Stodmarsh-Trenley Park Wood excursion were D. Stainer and R. G. Williams, and the Rev. Laurens Sargent led the Section on an expedition to the estuary of the Stour near Richborough. An evening was devoted to a conversazione arranged by the local committee. The exhibits included manuscripts shown by the Dean and Chapter and the charters of the King's School. Land, freshwater and marine life in all sections were displayed.

The 'Young Naturalists' Evening' commenced with a 'brain's trust' consisting of a team of experts, L. C. Bushby, Dr. L. B. Langmead, F. Rose and David Seth Smith, with Major Maxwell Knight as question master. Many questions received from students of local schools were answered. An exhibition of Nature films taken at the London Zoo by Douglas Fisher was enthusiastically received by an audience from the schools, the hall being filled to capacity.

The next congress will be held jointly with the South-Western Union at Marlborough during Whitsuntide, 1950.

\section{NATIONAL ACADEMY OF SCIENCES, UNITED STATES}

$\mathrm{T}$ HE National Academy of Sciences at its annual meeting held in Washington, D.C., during April 25-27, elected the following officers, members and foreign associates.

Vice-president for a four-year term ending in 1953 : Edwin Bidwell Wilson, emeritus professor of vital statistics, Harvard School of Public Health, Boston, Moss.

Members of the Council of the Academy for a threeyear term ending in 1952: Joel H. Hildebrand, professor of chemistry, University of California; Ernest W. Goodpasture, professor of pathology and dean, School of Medicine, Vanderbilt University.

Members : George W. Bartelmez, professor of anatomy, University of Chicago ; Frank A. Beach, professor of psychology, Yale University; Robert B. Brode, professor of physics, University of California; Paul R. Burkholder, Eaton professor of botany, Yale University; Lowell T. Coggeshall, professor and chairman, Department of Medicine, and dean, Division of Biological Sciences, University of Chicago; Max Delbrück, professor of biophysics, California Institute of Technology; Robert C. Elderfield, professor of chemistry, Columbia University ; William F. Gibbs, vice-president, Gibbs and Cox, 240 East 79th Street, New York; William W. Hansen, professor of physics, Stanford University; Charles B. Huggins, professor of surgery, University of Chicago ; Walter D. Lambert, U.S. Coast and Geodetic Survey (retired), Washington, D.C. ; Howard B. Lewis, professor and head of Department of Physiological Chemistry, University of Michigan; Francis W. Loomis, professor and head of Department of Physics, University of Illinois; Thomas S. Lovering, U.S. Geological Survey, Washington, D.C. ; Samuel M. McElvain, professor of chemistry, University of Wisconsin Saunders MacLane, professor of mathematics, University of Chicago ; Nicholas U. Mayall, Lick Observatory, Mt. Hamilton, California; Otto Meyerhof, research professor of physiological chemistry, University of Pennsylvania; John S. Nicholas, Sterling professor of biology, Yale University; George B. Pegram, professor of physics and dean of graduate faculties, Columbia University; Kenneth S. Pitzer, professor of chemistry, University of California; Kenneth B. Raper, senior microbiologist, Northern Regional Research Laboratory, U.S. Department of Agriculture, Peoria, Illinois; John L. Savage, chief designer, U.S. Bureau of Reclamation, Denver, Colorado; Carl F. Schmidt, professor of pharmacology, University of Pennsylvania ; Julian Schwinger, professor of physics, Harvard University; Harry L. Shapiro, professor of anthropology, Columbia University ; Oliver R. Wulf, professor, Division of Chemistry and Chemical Engineering, California Institute of Technology ; Ralph W. G. Wyckoff, scientist director, National Institute of Health, Bethesda, Maryland; Frederick W. H. Zachariasen, professor and chairman of the Department of Physics, University of Chicago.

Foreign Associates: Élie Cartan, professor of geometry, University of Paris; Paul A. M. Dirac, Lucasian professor of mathematical physics in the University of Cambridge ; Bernard Lyot, astronomer, Meudon Observatory, Seine-et-Oise, France; Henri Piéron, Laboratory of Physiological Psychology, Sorbonne; Arne Tiselius, professor of biochemistry, University of Uppsala; Öjvind Winge, director, Department of Physiology, Carlsberg Laboratory, Copenhagen; Hideki Yukawa, professor of physics, Kyoto University, Japan.

\section{Awards for 1948}

The Academy has made the following awards for 1948 .

Cyrus B. Comstock Prize of 3,500 dollars: to Dr. Merle Anthony Tuve, director of the Department of Terrestrial Magnetism of the Carnegie Institution of Washington, for his pioneering work on the upper atmosphere and his development of the electrical impulse method of study ; for his pioneering work in nuclear physics utilizing the electrostatic generator; and for his development of the proximity fuse.

James Craig Watson Gold Medal : to Dr. Samuel Alfred Mitchell, director for more than thirty years of the Leander McCormick Observatory of the University of Virginia, for distinguished services to astronomy, including (1) observations of solar eclipses, in particular a detailed study of the spectrum of the chromosphere which has contributed notably to knowledge of the atmosphere of the sun; (2) determination of the magnitudes of eight thousand comparison stars in 450 fields containing long-period variables, and more than fifteen thousand observations (with others) of 204 of the variables themselves ; (3) trigonometrical measurement of the parallaxes of some fifteen hundred stars.

Mary Clark Thompson Gold Medal : to Dr. Frank McLearn, of the Geological Survey of Canada, in recognition of his important contributions to geological knowledge in a number of fields.

Public Welfare Medal: to Prof. George Harrison Shull, emeritus professor of botany and genetics, Princeton University, for his services in the application of principles of the pure line and of hybrid vigour to the improvement of the quantity and quality of the maize crop. 